\title{
A new species of the genus Smacigastes Ivanenko \& Defaye, 2004 (Tegastidae, Harpacticoida, Copepoda) from the Onnuri Vent Field in the Indian Ocean
}

\author{
Jong Guk Kim ${ }^{1}$, Jimin Lee ${ }^{1}$ \\ 1 Marine Ecosystem Research Center, Korea Institute of Ocean Science \& Technology, Busan 49111, South Korea \\ http://zoobank.org/B40EF7CC-1A0E-4D3E-87F3-7E0CCDF0B441 \\ Corresponding author: Jimin Lee (jmlee@kiost.ac.kr)
}

Academic editor: Kay Van Damme • Received 20 May 2020 • Accepted 14 September 2020 • Published 9 October 2020

\begin{abstract}
The genus Smacigastes Ivanenko \& Defaye, 2004 (Harpacticoida, Copepoda) is the most primitive genus in the family Tegastidae Sars, 1904, occurring in deep-sea chemosynthetic environments, such as hydrothermal vents, cold seeps, whale falls and wood falls. Our exploration of the Onnuri Vent Field, the sixth active hydrothermal vent system in the Central Indian Ridge, resulted in the discovery of a new species in the genus Smacigastes. A detailed morphological analysis of S. pumila sp. nov. reveals that it most resembles S. barti Gollner, Ivanenko \& Martínez Arbizu, 2008, described from a hydrothermal vent in the East Pacific Ridge; the new species can be distinguished from the existing species by the 8 -segmented female antennule, the absence of an abexopodal seta on the antennary basis, the mandibular exopod represented by a single seta and the exopod of the first leg with five setae. This is the first record of Smacigastes in the Indian Ocean. A dichotomous key to species of the genus Smacigastes worldwide is provided.
\end{abstract}

\section{Key Words}

deep sea, dichotomous key, hydrothermal vent, meiofauna, northern Central Indian Ridge

\section{Introduction}

Deep-sea hydrothermal vents are special ecosystems maintained by chemosynthetic organisms that use dissolved mineral deposits (e.g. sulphide and methane) as a primary energy source, independent of solar energy (Nakamura and Takai 2015). Since the first discovery of hot springs in the Galápagos Archipelago, ecological and taxonomical information regarding hydrothermal fauna has accumulated worldwide (e.g. Hashimoto et al. 2001; Desbruyères et al. 2006; Rogers et al. 2012; Goffredi et al. 2017). Although copepods are a common and diverse group in this chemosynthetic habitat (Humes and Segonzac 1998; Heptner and Ivanenko 2002; Zeppilli et al. 2018), knowledge of this taxon is very limited due to the difficulty of sampling and because most scientific attention has been given to macro- or mega-fauna. Amongst hydrothermal copepod assemblages, dirivultid copepods belonging to the order
Siphonostomatoida are the most dominant constituents (Ivanenko et al. 2011, 2012; Sarrazin et al. 2015; Lee et al. 2020); however, some studies have suggested that the order Harpacticoida might have greater species richness compared to Siphonostomatoida (Willen 2004; Cuvelier et al. 2014; Plum et al. 2017). Although fewer than 20 hydrothermal harpacticoid copepods have been documented thus far (Heptner and Ivanenko 2002; Willen 2004, 2006; Ivanenko and Defaye 2006; Plum and Martínez Arbizu 2009; Back et al. 2010; Ivanenko et al. 2011), many species still remain to be described (Willen 2004).

The family Tegastidae Sars, 1904, comprising 69 valid species in seven genera, is a harpacticoid group that is easily recognisable by the laterally-compressed and amphipod-like bodies (Plum and Martínez Arbizu 2009; Saetang and Maiphae 2015; Huys 2016; Kim et al. 2016). Although most tegastid copepods live in algal habitats, occasionally in association with other 
invertebrates in shallow waters (Boxshall and Halsey 2004; Wells 2007; Huys 2016), deep-sea tegastids of the genus Smacigastes Ivanenko \& Defaye, 2004, as well as the species Tegastes okinawaensis Back, Huys \& Lee, 2010 and T. satyrus (Claus, 1860) occur in chemosynthetic ecosystems (e.g. hydrothermal vents, cold seeps, whale falls and wood falls) (Ivanenko and Defaye 2004; Gollner et al. 2008; Plum and Martínez Arbizu 2009; Willems et al. 2009; Back et al. 2010). In hydrothermal habitats, Smacigastes species occasionally exhibit a relatively high abundance (Sarrazin et al. 2015; Plum et al. 2017) and preference for hard-substrate environments (Gollner et al. 2008). Thus far, this genus accommodates only three named species and one undescribed species: S. micheli Ivanenko \& Defaye, 2004 from the Mid-Atlantic Ridge, S. barti Gollner, Ivanenko \& Martínez Arbizu, 2008 from the East Pacific Ridge, S. methanophilus Plum \& Martínez Arbizu, 2009 from the Gulf of Mexico and Smacigastes sp. from the Gorda Ridge (Ivanenko and Defaye 2004; Gollner et al. 2008; Plum and Martínez Arbizu 2009).

The Onnuri Vent Field (OVF), an active hydrothermal vent field in the Central Indian Ridge, was recently discovered by a research team from the Korean Institute of Ocean Science and Technology (KIOST). A survey of hydrothermal fauna in this ultramafic-hosted system resulted in the discovery of a tegastid harpacticoid that can be assigned to Smacigastes. Herein, we describe both sexes of $S$. pumila sp. nov. in detail and provide a dichotomous key to species of the genus Smacigastes. This is the first record of Smacigastes in the Indian Ocean.

\section{Materials and Methods}

An oceanographic expedition to the OVF, an ultramafic-hosted hydrothermal system and the sixth hydrothermal vent system discovered in the Indian Ocean, was conducted aboard the RV ISABU (15 June-3 July 2018; Fig. 1). Hydrothermal fauna was collected using a video-guided hydraulic grab (Oktopus, Germany) at a depth of $2022 \mathrm{~m}$; bathymodiolin mussels of the species Bathymodiolus marisindicus Hashimoto, 2001, Bathymodiolus sp. 1 and Gigantidas vrijenhoeki Jang, Ho, Jun, Kim \& Won, 2020 were dominant (Jang et al. 2020; Kim et al. 2020). To subsample meiofaunal assemblages, the collected macrofaunal animals and sediments taken by a trowel were rinsed with fresh water through a 50- $\mu \mathrm{m}$ mesh net. All subsamples were immediately fixed with a $4 \%$ formaldehyde solution. In the laboratory, meiofaunal animals were extracted by centrifugation using a Ludox HS40 at $2400 \mathrm{rpm}$ (Heip et al. 1985). Tegastid harpacticoids were sorted from the extracted organisms under a stereomicroscope (Leica M165C, Germany) and were immersed in a 3\% glycerine solution in a desiccator to gradually replace their content medium with glycerine. All drawings were made from the holotype and allotype with the aid of a drawing tube mounted on a differential interference

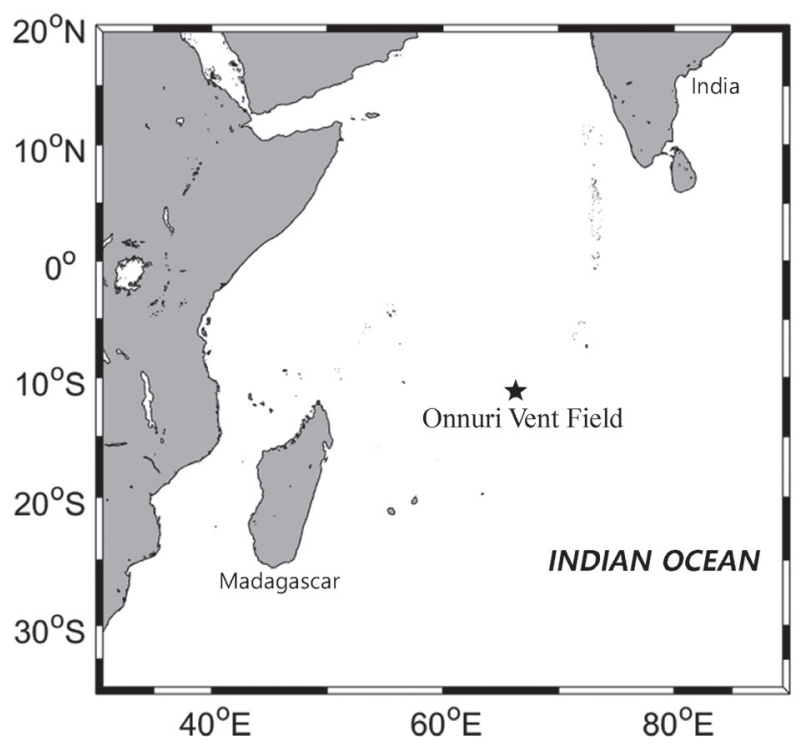

Figure 1. Map of the Onnuri Vent Field (Indian Ocean), black star showing the sampling station.

contrast microscope (DIC; Leica DM2500, Germany). The dissected parts were mounted in glycerine on H-S slides. Some specimens of the new tegastid harpacticoid were prepared for examination by scanning electron microscopy (SEM; Hitachi S-4300, Japan); the detailed process for SEM was performed using the method described by Chang (2013). A series of type material was deposited in the Marine Biodiversity Institute of Korea (MABIK), Seochun, South Korea and the examined scanning electron microscopy stub was kept in the Korea Institute of Ocean Science and Technology (KIOST), Busan, South Korea. The general descriptive terminology follows that of Huys and Boxshall (1991) and the setal formula follows that of Huys et al. (1996). The scale bar in the illustrations of the new taxon is given in $\mu \mathrm{m}$.

Abbreviations used in the text are: ae $=$ aesthetasc; enp-1(-2, -3) = proximal (middle, distal) segment of endopod; exp-1(-2, -3) = proximal (middle, distal) segment of exopod; $\mathrm{L} / \mathrm{W}=$ length to greatest width; $\mathrm{P} 1-\mathrm{P} 6=$ first to sixth thoracic leg.

\section{Results}

\section{Taxonomic accounts}

\section{Order Harpacticoida Sars, 1903 \\ Family Tegastidae Sars, 1904}

Genus Smacigastes Ivanenko \& Defaye, 2004

\section{Smacigastes pumila sp. nov.}

http://zoobank.org/34FBE107-EEC4-457D-8720-DADBF4E4FFD4 Figs 2-8

Etymology. The specific name pumila is derived from the Latin adjective pumilus meaning "dwarfish" and refers 
the relatively short caudal seta IV, shorter than the caudal ramus length.

Type material. Holotype. INDIAN OCEAN - OVF - $q$ dissected on 12 slides; the Central Indian Ridge, $11^{\circ} 24.88^{\prime} \mathrm{S}, 66^{\circ} 25.42^{\prime} \mathrm{E}$; depth $2020 \mathrm{~m}$; 24 Jun 2018; J. Lee leg.; MABIK CR00247427.

Allotype. INDIAN OCEAN - OVF - o dissected on 12 slides; sampling data as holotype; MABIK CR00247428.

Paratypes. INDIAN OCEAN - OVF $\bullet 2 \circ+10$ dissected on 12 slides, respectively; sampling data as holotype; MABIK CR00247429-CR00247431・2우, 2ふふふ઼ preserved together in $95 \%$ ethanol; sampling data as holo-

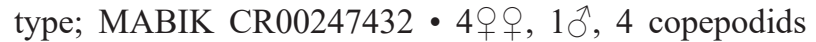
preserved together in $95 \%$ ethanol; sampling data as holotype; MABIK CR00247433.

Other materials. INDIAN OCEAN - OVF・3우, $2 \lesssim え$ on a stub for SEM; sampling data as holotype.

Description. Female. Habitus (Figs 2A, 8A) compressed laterally, with weakly chitinised integuments covered with sensilla and pores. Total length of holotype $669.2 \mu \mathrm{m}$ (range 625.9-703.7 $\mu \mathrm{m}$, mean $670.7 \mu \mathrm{m}, \mathrm{n}=9$ ) from tip of rostrum to end of caudal rami in lateral aspect; maximum width $233.6 \mu \mathrm{m}$ measured at distal third of cephalothorax including ventrolateral expanded area. Rostrum prominent, fused to cephalothorax, with one pair of sensilla subdistally. Prosome 4-segmented, comprising cephalothorax and three free pedigerous somites. Cephalothorax occupying about $43 \%$ of total length, slightly shorter than four succeeding somites combined; cephalic shied expanded ventrolaterally; expanded area gradually tapering ventrally. Pedigerous somites with lateral groove on epimeral area. Urosome (Figs 2A, 3A, B, 8A) 5-segmented, composed of P5-bearing somite, genital double-somite and three abdominal somites. P5-bearing somite about 0.7 times as long as preceding somite. Genital double-somite completely fused, armed with one pair of pores dorsolaterally, one pair of sensilla dorsodistally and two pairs of pores and four sensilla ventrodistally. Genital field (Fig. 3B, C) located at anterior fourth on ventral surface of genital double-somite; gonopore fused medially, reversed U-shaped, covered by a single plate bearing one seta, representing the P6, on each side; copulatory pore unrecognised. Second abdominal somite short, with one pair of pores ventrolaterally. Third abdominal somite short, unornamented. Anal somite 1.7 times longer than preceding one, with one pair of long sensilla and one pair of pores dorsolaterally; anal opening (Figs 3A, 8B) wide, with triradiate membranes armed with fine setules; operculum wide, semi-rounded, unornamented.

Caudal rami (Figs 2B, 3A, B, 8B) distinctly spaced apart from each other, about 2.9 times as long as maximum width, with slightly convex inner margin; with one posterior and two lateral pores ventrally; with seven caudal setae: seta I about 0.7 times as long as ramus; seta II longest, inserted in dorsal surface, about 2.2 times as long as ramus; seta III issuing from distal fourth of lateral margin, slightly shorter than seta II; distal seta IV slightly longer than seta VI; principal seta V well-developed, about 3.5 times as long as ramus; seta VI shortest, about half as long as ramus, inserted at distal inner corner; seta VII tri-articulated basally, close to seta III, nearly as long as ramus; all setae bare except for weakly pinnate seta $\mathrm{V}$.

Antennule (Fig. 4A) 8-segmented, elongate; first segment with one bare seta; second segment longest, with 10 setae; third segment with nine setae; fourth segment with four setae and one ae; fifth segment with two setae; sixth segment with four setae; first to sixth segments with all non-articulate and naked setae; seventh segment shortest, with two bi-articulated and two non-articulate setae; eighth segment twice as long as previous one, with four bi-articulated setae along lateral margin, one small and two long bare setae, and one ae on distal margin. Each ae fused basally to adjacent seta. Length ratio of antennular segments, $1.0: 1.40: 0.89: 0.63: 0.46: 0.48: 0.41: 0.84$. Setal armature as I-[1], II-[10], III-[9], IV-[3 + $(1+\mathrm{ae})]$, V-[2], VI-[4], VII-[4], VIII-[6+ $(1+\mathrm{ae})]$.

Antenna (Fig. 5A). Basis elongate, without abexopodal seta; outer margin armed with several rows of small spinules; inner margin armed with one row of small spinules medially and one group of long setules distally; medial surface with one row of spinules proximally and one row of tiny spinules distally. Exopod small, 2-segmented; proximal segment with one unipinnate seta distally; distal segment about half as long as preceding one, with one unipinnate seta subdistally and two weakly-pinnate setae distally. Endopod elongate, 2-segmented; proximal segment with one pinnate seta and armed with outer spinules; distal segment about 1.2 times as long as proximal one, armed with three groups of spinules along outer margin, two groups of spinules on inner margin proximally, two groups of small spinules and one surface frill on medial surface and one surface frill on distal margin; lateral armature composed of one pinnate seta proximally and set of one long pinnate seta, one small pinnate seta and one small bare seta subdistally; apical armature with seven setae consisting of three weakly-pinnate setae, one long unipinnate seta, one small spinulose seta and two long bare setae, one of which is longer than total length of endopod.

Mandible (Fig. 5B). Coxa stout, well-developed, with one protuberance medially; gnathobase armed with five multicuspidate teeth and one unipinnate dorsal seta. Palp uniramous, consisting of basis, 1-segmented endopod and rudimental exopod; basis with two long plumose setae apically and one row of spinules laterally; exopod represented by one unipinnate seta; endopod elongate, 1-segmented, with one bare, one proximally spinulose and one plumose setae apically and one pinnate seta laterally, armed with three groups of spinules on surface.

Maxillule (Fig. 5C). Praecoxal arthrite well-developed, with one group of spinules on dorsal margin; distal armature composed of one bare seta and one apically-pinnate seta subdistally and seven serrate spines distally, of which most ventral spine having bifid tip. Coxal endite with one spinulose seta distally. Basis broad, with two rows of small spinules anteriorly; distal endite with one stout 


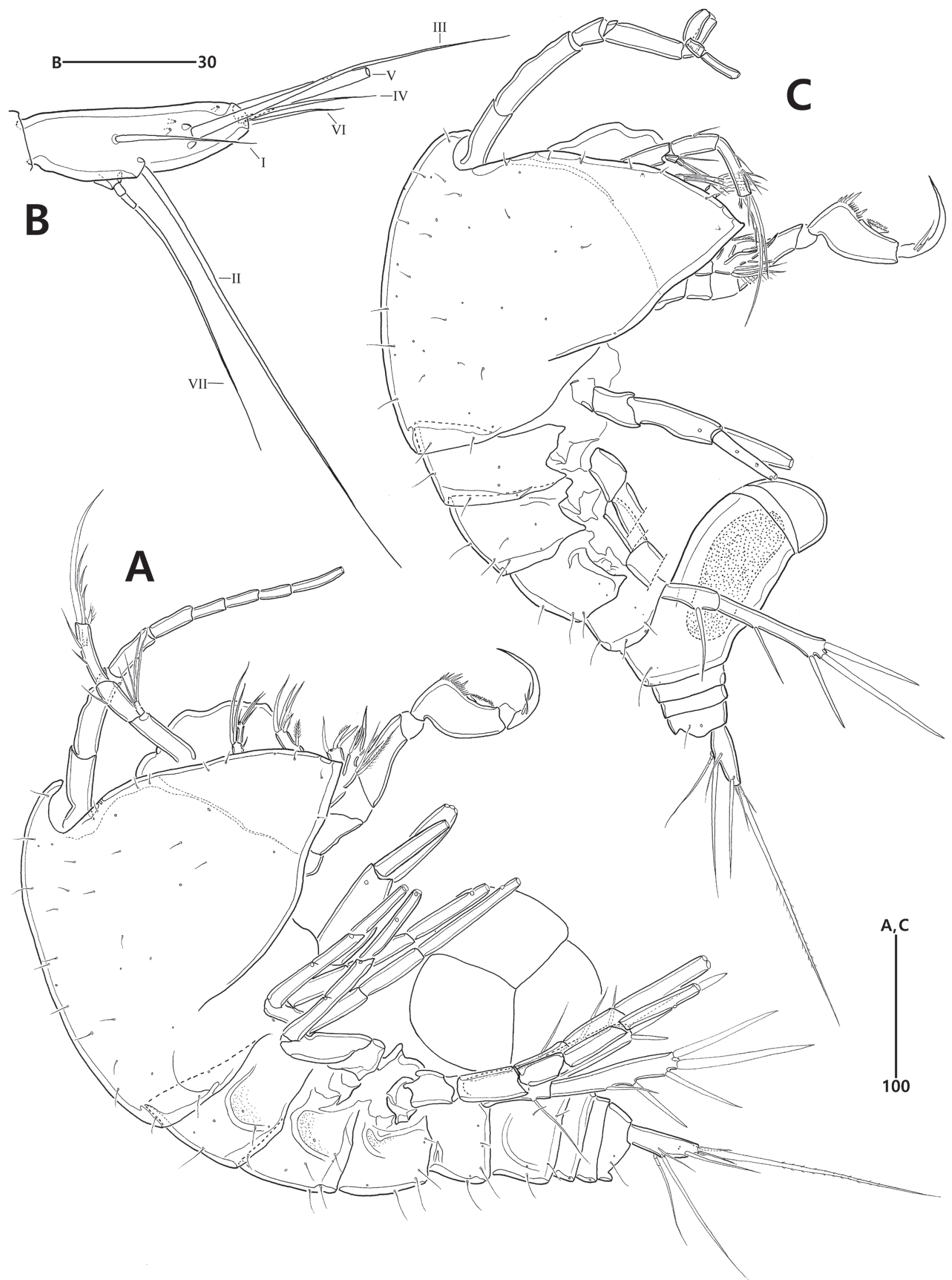

Figure 2. Smacigastes pumila sp. nov., female (A, B). A. Habitus, lateral; B. Caudal ramus, lateral. Male (C), C. Habitus, lateral. 


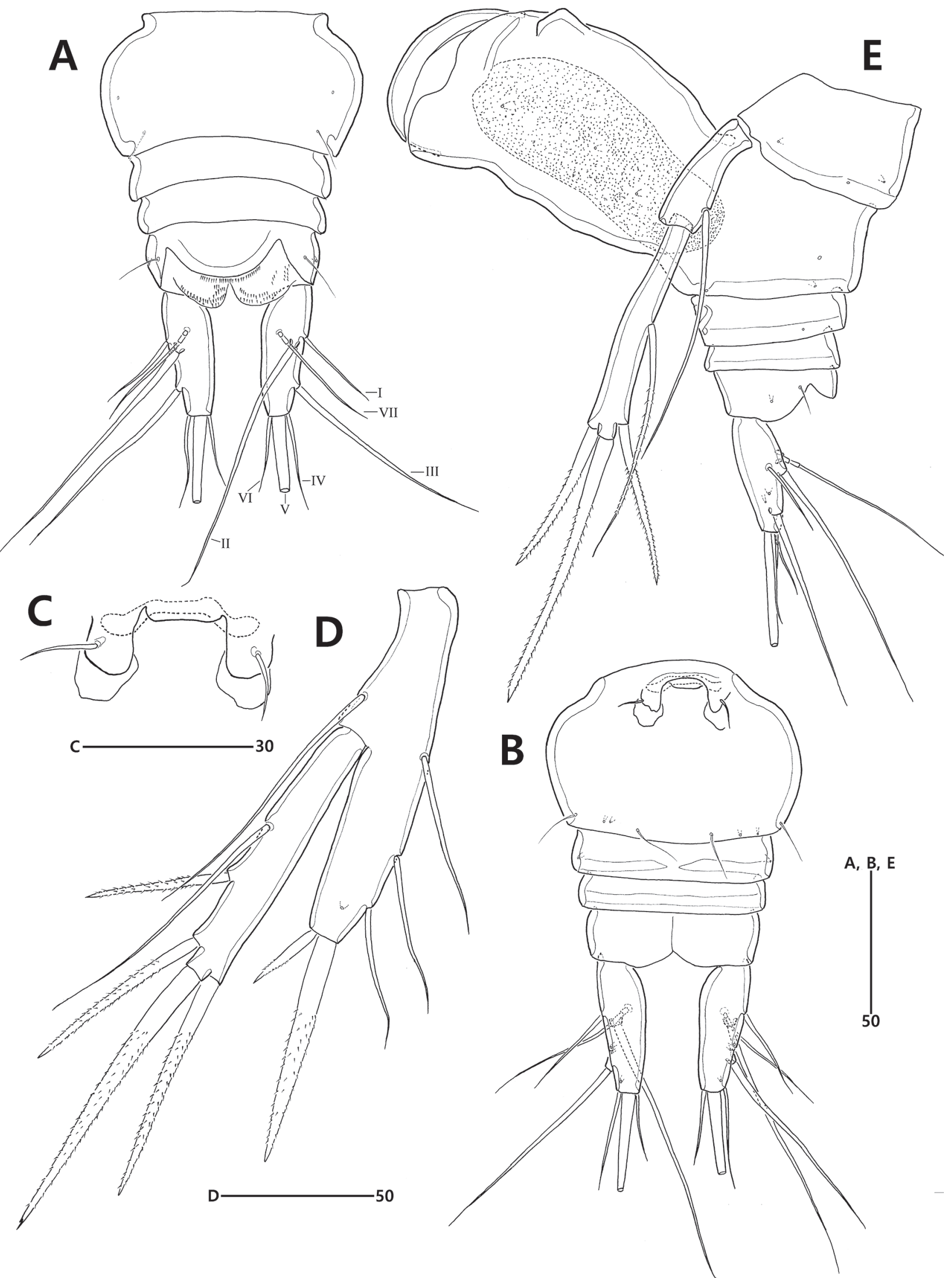

Figure 3. Smacigastes pumila sp. nov., female (A-D). A. Urosome excluding P5-bearing somite, dorsal; B. Urosome excluding P5-bearing somite, ventral; C. Genital field; D. P5. Male (E), E. Urosome and P5, lateral. 


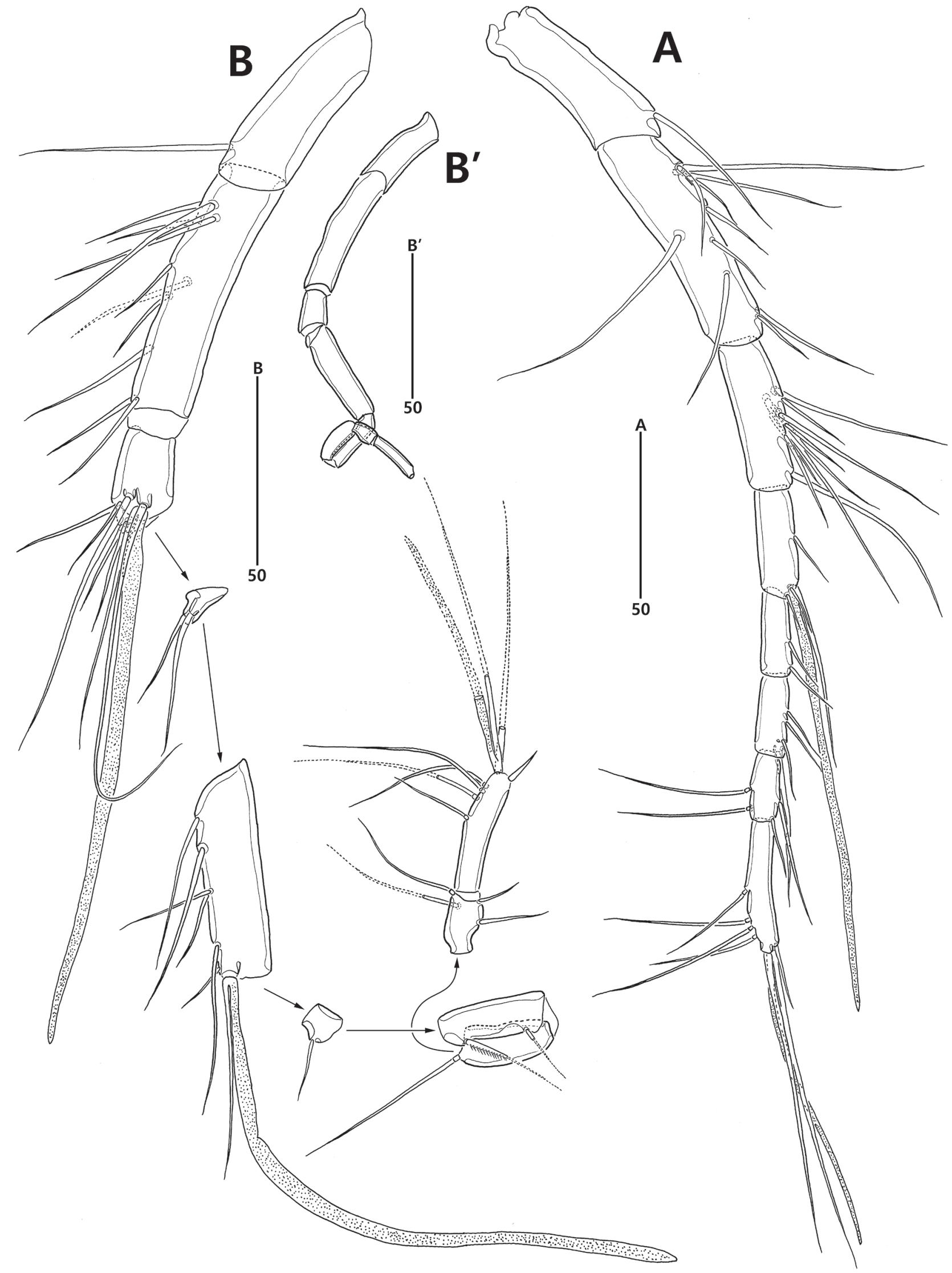

Figure 4. Smacigastes pumila sp. nov., antennules. A. Female; B. Male. 
spinulose seta subdistally, two densely-pinnate setae and one weakly-unipinnate seta, of which two dorsal setae are armed with long spinules proximally. Exopod elongate, 1-segmented, armed with one row of lateral setules, with one spinulose seta subdistally and one weakly-pinnate seta distally. Endopod incorporated in basis, represented by one small pinnate seta and one stout spinulose seta.

Maxilla (Fig. 5D). Syncoxa elongate, with one group of long setules subdistally on outer margin; with three endites: praecoxal endite elongate, parallel to inner margin of syncoxa, with one spinulose seta and one plumose seta laterally and two plumose setae, of which the inner one elongate, longer than syncoxa, distally; proximal coxal endite with two spinulose setae distally; distal coxal endite largest, gradually widening towards distal end, with one pinnate seta subdistally and two spinulose setae distally. Basis apically with stout claw bearing one row of spinules, with one bare seta ventrally, one stout spinulose seta dorsally and one tube pore. Endopod incorporated into basis, represented by one uniplumose and two pinnate setae.

Maxilliped (Figs 5E, F, 8C, D) subchelate, inserted on pedestal, 3-segmented, composed of syncoxa, basis and endopod. Pedestal small, unornamented. Syncoxa elongate, with one unipinnate seta subdistally, two groups of long spinules on medial surface and two groups of setules on inner margin. Basis shorter than syncoxa, with swollen outer margin with one group of long setules; palmar margin concave, distally with one predominant tonguelike process bearing numerous small papilla on its surface; proximal part swollen, with one small spine, one row of medial spinules and two rows of median spinules, of which spinules of proximal one gradually increasing in size. Endopod drawn out into serrate claw accompanying two inner and three outer accessory setae, of which the outer one very small (Fig. 8C, arrowhead).

P1 (Fig. 6A). Intercoxal sclerite wide, unornamented. Coxa slightly longer than its width, unornamented. Basis elongate, gradually widening towards distal end, with one slender, bare outer seta, without inner element; pedestal of exopod developed, armed with one patch of anterior spinules. Exopod 1-segmented, slender, shorter than basis, armed with outer minute spinules anteriorly and long inner setules; with three pinnate outer setae and two densely pinnate apical setae, of which the outer one about 3.3 times as long as the inner. Endopod broad, slightly longer than exopod, with one plumose seta proximally and two densely pinnate setae subdistally on inner margin and three pinnate setae, of which the innermost one stout, with spinules on all sides and the central one armed with inner setules, on apical margin; with one pore on outer margin subdistally (Fig. 6A, arrowhead).

P2-P4 (Figs 6B, 7A, B). Intercoxal sclerites wide, slightly arched, unornamented; anterior surfaces of P2P3 with one pair of two hollows. Coxae gradually tapering towards distal end; distal tip with one group of spinules.
Bases transversely elongate, with one slender, bare outer seta. Exopods shorter than endopods (distinctly shorter in P2-P3 and slightly shorter in P4), 3-segmented assumptively in P2-P3 and completely in P4; P2-P3 exp-1 and exp-2 fused, but original segmentation between them retained partially by anterior traces (incomplete sutures); each segment armed with minute outer spinules; exp-1 with one weakly-pinnate outer seta (in P2-P3) or bare seta (in P4); P2-P3 exp-1 with one plumose inner seta; exp-2 with one pinnate outer spine and one long plumose inner seta; exp-3 longest, with two pinnate outer spines, two plumose apical setae, of which outer one armed with minute outer spinules and one anterior pore distally (absent in P2); P2 exp-3 with two plumose inner setae, P3 exp-3 with three plumose inner setae and P4 exp-3 with two plumose setae and one distally-serrate seta (central). Endopod 3-segmented; each segment armed with outer setules or spinules; enp-1 with one long plumose inner seta (distally pinnate in P2 and P4); enp-2 with two long plumose inner setae (distally pinnate in P4); enp-3 longest, with one pinnate outer spine, two stout pinnate apical spines and one distal anterior pore; P2 and P4 enp-2 with two plumose (in P2) or pinnate (in P4) setae and P3 enp-3 with three plumose inner setae. Setal armature formulae of P2-P4 as follows:

$\begin{array}{lll} & \text { Exopod } & \text { Endopod } \\ \text { P2 } & 2.222 & 1.2 .221 \\ \text { P3 } & 2.322 & 1.2 .321 \\ \text { P4 } & 0.1 .322 & 1.2 .221\end{array}$

P5 (Fig. 3D). Baseoendopod elongate, with one long bare seta on outer margin; endopodal lobe well-developed, extending to distal third of exopod, with three long bare setae on inner margin and one stout spinulose (on all sides) and one small pinnate spine on apical margin; posterior surface with one pore subdistally. Exopod elongate, slender, unornamented, with three outer elements consisting of one long bare seta proximally and two stout spinulose (on all sides) spines subdistally and distal elements composed of two stout spinulose (on all sides) spines, of which outer one longer than inner.

Male. Body (Figs 2C, 8E) length of allotype about $527.1 \mu \mathrm{m}$ (range 527.1-592.6 $\mu \mathrm{m}$, mean $=558.8 \mu \mathrm{m}$, $\mathrm{n}=5$ ) measured from anterior tip of rostrum to posterior end of caudal rami in lateral aspect. Sexual dimorphism exhibited in antennule, genital double-somite and P5.

Urosome (Figs 2C, 3D, 8F) 5-segmented as in female by forming genital double-somite comprising genital somite and first abdominal somite. Genital double-somite with elongated, large ventral protuberance; distal tip of protuberance with asymmetrical genital flap representing P6; both genital flaps without elements, left one fused to body and right one articulated.

Antennule (Fig. 4B) 10-segmented, haplocer, with geniculation between seventh and eighth segments. First 


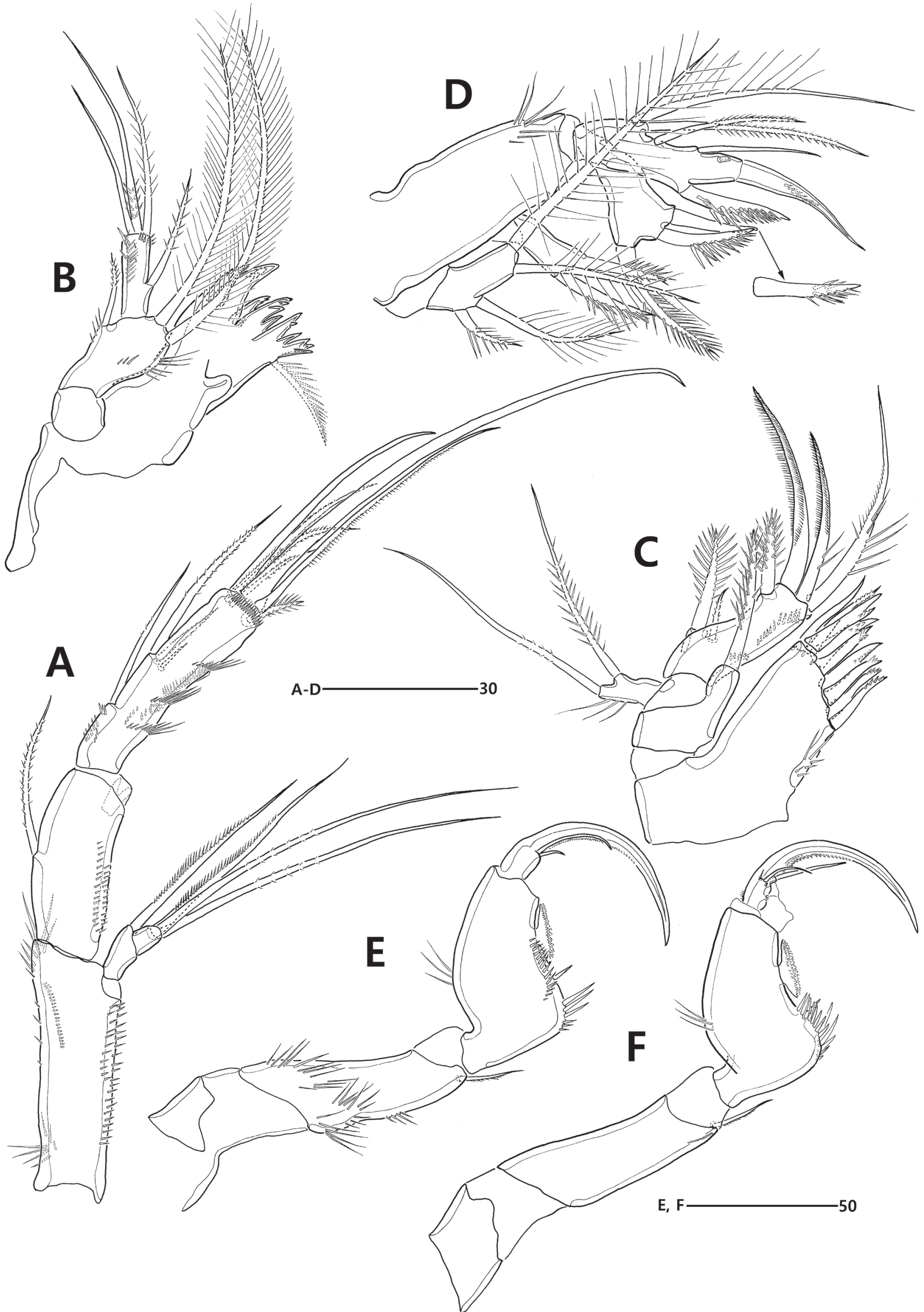

Figure 5. Smacigastes pumila sp. nov., female. A. Antenna; B. Mandible; C. maxillule; D. Maxilla; E. Maxilliped, medial; F. Maxilliped, lateral. 


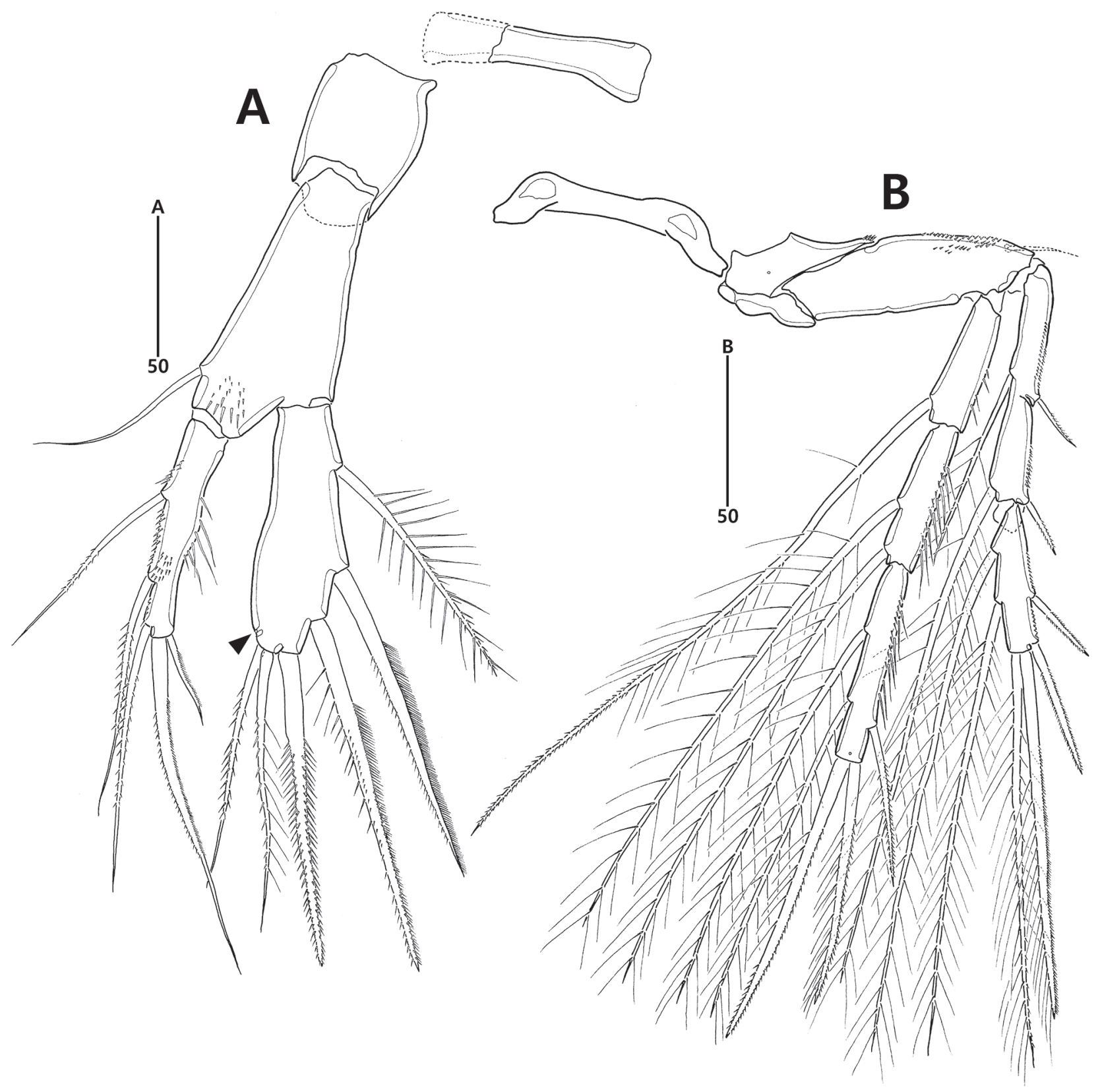

Figure 6. Smacigastes pumila sp. nov., female. A. P1 (arrowhead indicates a pore); B. P2.

segment elongate, with one long bare seta distally. Second segment longest, about 1.4 times as long as preceding one, with 10 setae laterally. Third segment small, slightly longer than its width, with seven setae and one ae. Fourth segment smallest, wedge-shaped, with two setae. Fifth segment elongate, about 3.5 times as long as wide, with six lateral setae and one subdistal peduncle bearing one seta and one ae. Sixth segment small, with one seta. Seventh segment slender, with one uniplumose seta proximally and one bare seta subdistally. Eighth segment as long as preceding one, with one bi-articulate seta subdistally. Ninth segment small, with two bi-articulate and two non-articulate setae. Tenth segment slightly longer than seventh segment, with four bi-articulate setae on lateral margin and one small seta, two long bare setae and one ae on distal margin. Each ae fused to adjacent seta basally. Setal armature as follows: I-[1], II-[9], III-[6+ $(1+\mathrm{ae})]$,
IV-[2], V-[6 + (1 + ae)], VI-[1], VII-[2], VIII-[1], IX-[4], $\mathrm{X}-[6+(1+\mathrm{ae})]$.

P5 (Figs 2C, 3E) 2-segmented, elongate, nearly as long as urosome; baseoendopod about twice as long as wide, with one outer seta; endopodal lobe undeveloped; exopod elongate, about 1.9 times as long as baseoendopod, with one weakly-pinnate seta proximally and one pinnate spine subdistally on lateral margin and two pinnate spines on distal margin.

Remarks. Differentiation of Smacigastes species has demanded detailed attention to the setation of cephalosomal appendages, the segmentation of the P2-P3 exopods, the shape and ornamentation of P5 in both sexes and the shape of elements on P5 (Gollner et al. 2008; Plum and Martínez Arbizu 2009). When Ivanenko and Defaye (2004) erected the genus Smacigastes, they designated that P2-P4 of the genus Smacigastes are 3-segmented, 


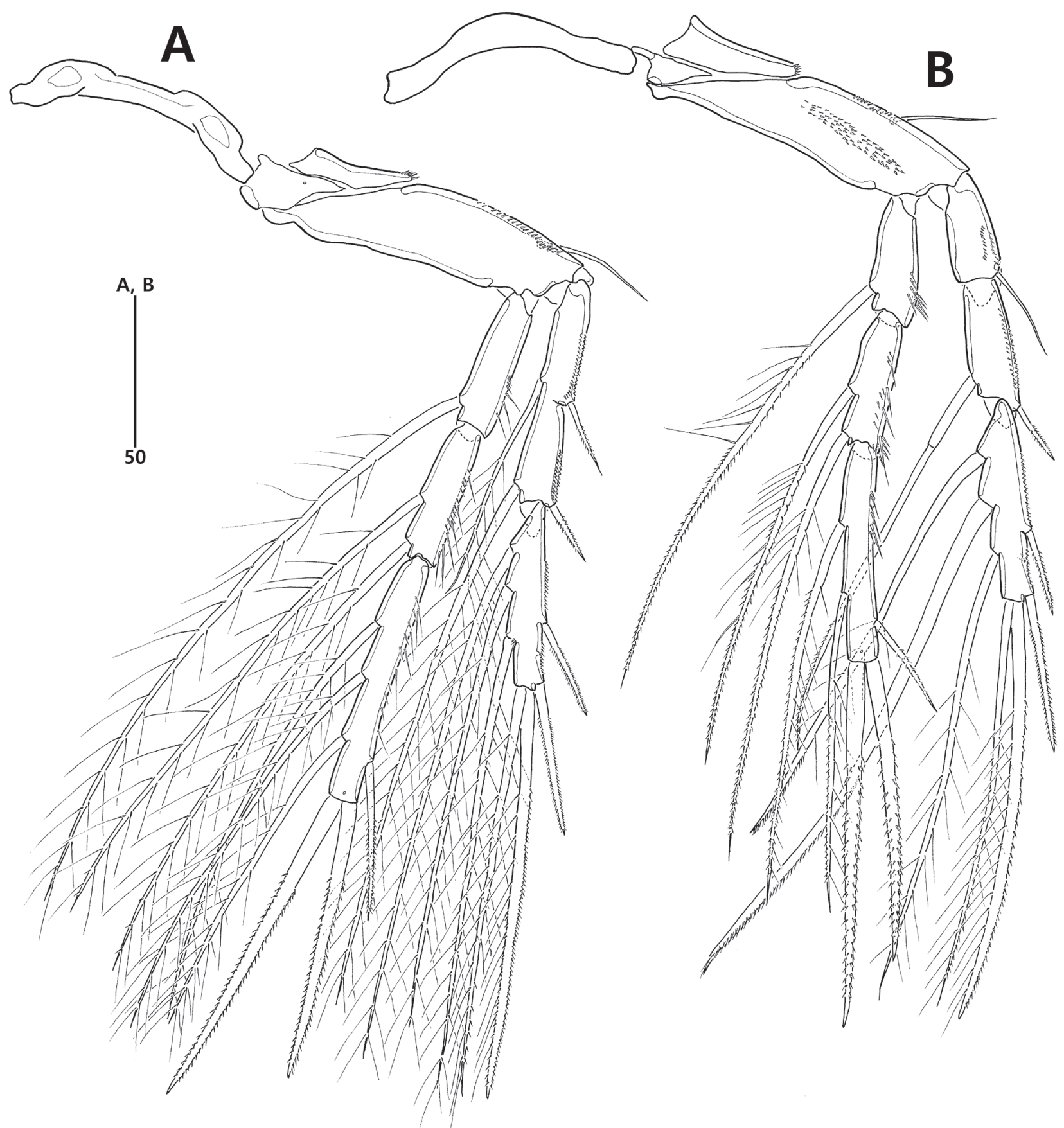

Figure 7. Smacigastes pumila sp. nov., female. A. P3; B. P4.

based on the characteristics of the type species, $S$. micheli, described from the Mid-Atlantic Ridge. However, all subsequent species (S. barti, S. methanophilus and $S$. pumila sp. nov.) have 2-segmented exopods of P2-P3. In a study of the development of $S$. barti, Gollner et al. (2008) presumed that the 2-segmented exopods of P2-P3 resulted from the fusion of proximal and middle exopodal segments through a developmental process from copepodid phase V to phase VI (adult). A trace of the original division between these segments remains in the incomplete anterior suture of $S$. methanophilus and $S$. pumila sp. nov. and in a fissure in $S$. barti (Gollner et al. 2008; Plum and Martínez Arbizu 2009). In addi- tion, S. micheli can be clearly distinguished from other congeners by the presence of three exopodal setae on the mandibular palp and the relatively short elements on both rami of the female $\mathrm{P} 5$.

Smacigastes pumila sp. nov. is morphologically similar to S. methanophilus in the main characteristics of the setal armature of the antenna and maxilla, the segmentation condition of the thoracic legs and the shape of the P5 in both sexes. However, this new species is easily distinguished from the existing species by the presence of only one exopodal seta on the mandibular palp (vs. two setae in S. methanophilus); two setae on both maxillular rami (vs. three setae on each in S. methanophilus); the absence 


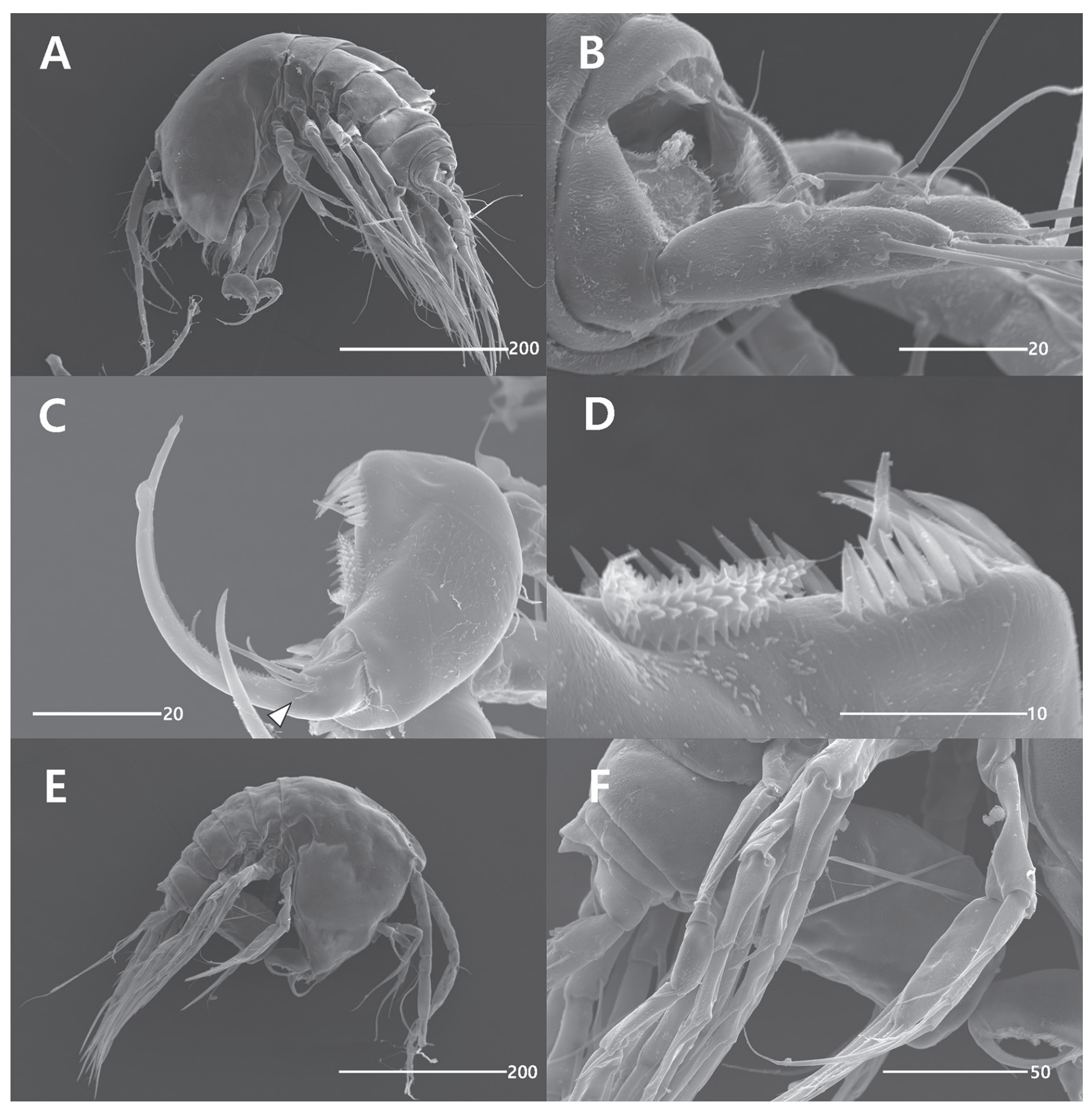

Figure 8. Smacigastes pumila sp. nov., SEM photographs, female (A-D). A. Habitus, lateral; B. Anal somite and caudal rami, lateral; C. Basis and endopod of maxilliped, lateral (arrowhead indicates a minute setal armature on the endopod); D. Ornamentation on the palmar margin of the maxillipedal endopod. Male (E, F), E. Habitus, lateral; F. Genital double-somite, lateral.

of a basal inner seta in the $\mathrm{P} 1$; the relative length of the inner seta on the P2-P3 exp-1, exceeding the end of exp-2 (vs. exceeding the end of the exopod in S. methanophilus); and the absence of anterior ornamentation on the P5 exopod in both sexes.

This new species morphologically resembles $S$. barti in two robust features: (1) loss of the inner seta in the P1 basis, which is an essential element in harpacticoid copepods, except for a few taxa [i.e. the family Parastenocarididae Chappuis, 1940 and the subfamily Clytemnestrinae A. Scott, 1909 (cf. Huys and Conroy-Dalton 2000; Corgosinho et al. 2008)]; and (2) presence of two setae on the exopod of the maxillule. The morphological differences between the two species, however, are notable, including (1) the antennule in the female of S. pumila sp. nov. has eight segments, whereas it is 7-segmented in $S$. barti; (2) there is no abexopodal seta on the antennary basis in $S$. pumila sp. nov., whereas this seta is present in $S$. barti; (3) the mandibular exopod is represented by a seta in $S$. pumila sp. nov., whereas it is absent in $S$. barti; (4) the syncoxa of the maxilla has three endites in S. pumila sp. nov., whereas the praecoxal endite is absent in $S$. barti; (5) the P1 exopod has five elements in $S$. pumila sp. nov., whereas it has only four elements in $S$. barti; (6) S. pumila sp. nov. has a broad P5 baseoendopodal lobe in the female, while it is much 
more slender in $S$. barti (L/W value is approximately 4.1 in $S$. barti vs. 2.8 in $S$. pumila sp. nov.); and (7) the exopod/baseoendopod length ratio of the male P5 is much greater (approximately 1.9) in S. pumila sp. nov. than in S. barti (approximately 1.1).
Detailed morphological differences that are sufficiently robust to justify the discrimination between Smacigastes species are given in Table 1 and the dichotomous key to species of the genus Smacigastes worldwide is provided below.

\section{Dichotomous key to species of the genus Smacigastes worldwide}

1 Exopods of P2-P3 3-segmented; mandibular exopod represented by three setae; the distal setae length on P5 exopod in female less than $1 / 3$ of exopod length.................................................................................. S. micheli

- $\quad$ Exopods of P2-P3 2-segmented by fusion of proximal and middle segments; mandibular exopod represented by 0-2 setae; the distal setae length on P5 exopod in female longer than half the length of the exopod at least.................... 2

2 Female antennule 7-segmented; antennary basis with an abexopodal seta; praecoxal endite of maxillary syncoxa absent; P1 exopod with four elements totally ............................................................................................... barti

- $\quad$ Female antennule of female 8-segmented; antennary basis without an abexopodal seta; praecoxal endite of maxillary syncoxa present; P1 exopod with five elements totally .................................................................... 3

3 Maxillular exopod with three setae; P1 basis with an inner element; P5 exopod in both sexes ornamented with anterior spinules ......................................................................................................................... methanophilus

- Maxillular exopod with two setae; P1 basis without inner elements; P5 exopod in both sexes unornamented.

S. pumila sp. nov.

Table 1. Comparison of morphological characters of Smacigastes species.

\begin{tabular}{|c|c|c|c|c|}
\hline Characters & S. micheli & S. barti & S. methanophilus & S. pumila sp. nov. \\
\hline A1 우 & 8-segmented & 7-segmented & 8-segmented & 8-segmented \\
\hline A2 basis, abexopodal seta & present & present & absent & absent \\
\hline A2 enp-2, distal armature & 6 elements & 6 elements & 7 elements & 7 elements \\
\hline Md gnathobase & without seta & unknown & with a pinnate seta & with a pinnate seta \\
\hline Md exopod, no. of setae & 3 setae & absent & 2 setae & 1 seta \\
\hline Md endopod, no. of setae & 1 lateral, 4 distal setae & 1 lateral, 3 distal setae & 1 lateral, 3 distal setae & 1 lateral, 3 distal setae \\
\hline $\begin{array}{l}\text { Mxl preacoxal arthrite, no. of } \\
\text { elements }\end{array}$ & 9 elements & 8 elements & 9 elements & 9 elements \\
\hline Mxl exopod, no. of setae & 3 setae & 2 setae & 3 setae & 2 setae \\
\hline Mxl endopod & represented by 3 setae & represented by 1 seta & represented by 3 setae & represented by 2 setae \\
\hline Mxa syncoxa, proximal endite & present & absent & present & present \\
\hline $\begin{array}{l}\text { Mxa syncoxa, middle endite, no. } \\
\text { of setae }\end{array}$ & 2 setae & 1 seta & 2 setae & 2 setae \\
\hline Mxp basis, L/W ratio & approximately 2.2 & approximately 1.7 & approximately 1.9 & approximately 1.6 \\
\hline $\begin{array}{l}\text { Mxp basis, palmar margin, } \\
\text { proximal element }\end{array}$ & plumose & spine-like & absent & spine-like \\
\hline P1 basis, inner seta & present & absent & present & absent \\
\hline P1 exopod, no. of setae & 5 setae & 4 setae & 5 setae & 5 setae \\
\hline P2-P4 basis, ornamentation & absent in all legs & present in P3 & present in all legs & present in all legs \\
\hline P2-P3 exp-1 and exp-2 & completely separate & $\begin{array}{c}\text { partially fused (original } \\
\text { division marked by a } \\
\text { fissure) }\end{array}$ & $\begin{array}{c}\text { partially fused } \\
\text { (original division marked } \\
\text { by an anterior suture) }\end{array}$ & $\begin{array}{c}\text { partially fused } \\
\text { (original division marked } \\
\text { by an anterior suture) }\end{array}$ \\
\hline $\begin{array}{l}\text { P2-P3 exp-1, length of inner } \\
\text { seta }\end{array}$ & exceeding end of exp-2 & $\begin{array}{l}\text { not exceeding end of } \\
\text { exp-2 }\end{array}$ & exceeding end of exp-3 & exceeding end of exp-2 \\
\hline P5 exopod,$+ \widehat{\partial}$, ornamentation & absent & absent & present & absent \\
\hline P5 benp lobe, length & $\begin{array}{l}\text { reaching to } 4 / 5 \text { length of } \\
\text { expod }\end{array}$ & $\begin{array}{c}\text { reaching to } 4 / 5 \text { length of } \\
\text { expod }\end{array}$ & $\begin{array}{c}\text { reaching to } 2 / 3 \text { length of } \\
\text { expod }\end{array}$ & $\begin{array}{c}\text { reaching to } 2 / 3 \text { length of } \\
\text { expod }\end{array}$ \\
\hline P5 benp lobe, L/W ratio & approximately 2.2 & approximately 4.1 & approximately 2.9 & approximately 2.8 \\
\hline $\begin{array}{l}\mathrm{P} 5 \text {, length of distal setae on } \\
\text { exopod }\end{array}$ & $\begin{array}{c}\text { less than } 1 / 3 \text { of exopod } \\
\text { length }\end{array}$ & longer than exopod & $\begin{array}{c}\text { longer than } 2 / 3 \text { length of } \\
\text { exopod }\end{array}$ & $\begin{array}{c}\text { longer than } 3 / 4 \text { length of } \\
\text { exopod }\end{array}$ \\
\hline P5 ô exopod/benp length ratio & approximately 2.0 & approximately 1.1 & approximately 2.0 & approximately 1.9 \\
\hline Seta IV/CR length ratio & 3 times & at least 2 times & at least 2 times & approximately 0.6 times \\
\hline References & $\begin{array}{l}\text { Ivanenko and Defaye } \\
2004\end{array}$ & Gollner et al. 2008 & $\begin{array}{c}\text { Plum and Martínez } \\
\text { Arbizu } 2009\end{array}$ & the present study \\
\hline
\end{tabular}

Abbreviations: $\mathrm{A} 1$ = antennule, $\mathrm{A} 2$ = antenna, benp = baseoendopod, $\mathrm{CR}=$ caudal rami, $\mathrm{L} / \mathrm{W}=$ length to maximum width, $\mathrm{Md}=$ mandible, $\mathrm{Mxa}=$ maxilla, $\mathrm{Mxl}=$ maxillule, Mxp = maxilliped. 


\section{Discussion}

There are 70 valid species, including S. pumila sp. nov., in seven genera of the family Tegastidae (Plum and Martínez Arbizu 2009; Saetang and Maiphae 2015; Huys 2016; Kim et al. 2016). The monophyly of this family is supported by the laterally-compressed, so-called "amphipod-like" body, as well as by the 1-segmented nature of both rami of $\mathrm{P} 1$. However, the phylogenetic relationship amongst tegastid representatives at the genus level remains somewhat unclear. For example, Kim et al. (2016) doubted the monophyly of the genus Syngastes Monard, 1924, based on the diverse morphological states of its congeners in the segmentations of the antennule and the antennary exopod, the shape of the P1 exopod, the setal armature of P2-P4 exp-1 and the male P5. Additionally, significant differences have been observed in the setation and segmentation of cephalosomal appendages within a single genus. Ivanenko and Defaye (2004) recognised differences in the number of endites in the maxillary syncoxa within the genus Tegastes Norman, 1903; only two endites are present in T. acroporanus Humes, 1981, T. harpactoides (Claus, 1863), T. paulipes Humes, 1984, T. pygmaeus Marcus, 1977, T. nanus Sars, 1904 and T. singularisaetus Marcus, 1977. In addition, some Tegastes species exhibit similar reduction of cephalosomal appendages: most Tegastes species have a 2-segmented exopod in the antenna, whereas a 1-segmented exopod is known in $T$. acroporanus, T. areolatus Monard, 1935, T. gemmeus Humes, 1984, T. georgei Marcus \& Masry, 1970, T. harpactoides, T. paulipes, T. satyrus (Claus, 1860) and T. singularisaetus (Claus 1860, 1863; Monard 1935; Marcus and Masry 1970; Marcus, 1977; Humes 1981a; Humes 1984); most tegastid species have a tongue-like process on the palmar margin of the maxillipedal endopod distally, although this feature is absent in T. acroporanus, T. gemmeus, T. harpactoides and T. paulipes and is represented by a tubercle in $T$. singularisaetus. Considering these differences, at least three species (T. acroporanus, $T$. paulipes and $T$. singularisaetus) appear quite distinct from other Tegastes species. This confusion might have resulted from the relatively-simple delimitation of tegastid genera, which were traditionally distinguished, based mainly on the number of segments in P2-P4 (Sars 1904; Marcus 1977; Humes 1981a, 1984). Wells (2007) presumed that this simple classification contradicts a recent phylogenetic analysis without inspection of the characteristic of the maxilliped, the female P5 and the anterior urosomites. Only recently, studies (Ivanenko and Defaye 2004; Ivanenko et al. 2008; Huys 2016) began to focus on the structures of the genital somite complex, the female $\mathrm{P} 5$, the torsion of the male genital somite and the length of caudal rami as generic characteristics. The re-appraisal and application of these morphological features to the modern taxonomy of the tegastid family have been hampered by the poor and inadequate descriptions of many tegastid species in incipient studies (i.e. Claus 1860,
1863; T. Scott 1894; Thompson and A. Scott 1903; Brady 1910), which especially lack information regarding cephalosomal appendages. Reliable information concerning the mouth-part appendages has been subsequently provided by various authors (i.e. Médioni and Soyer 1967; Marcus 1977; Bartsch 1993, 1994, 1995, 1999; Humes 1981a, b, 1984). A re-appraisal and cladistic analysis, based on the morphology of cephalosomal appendages, would help to clarify the phylogenetic relationship of tegastid species. Further revisional works should re-examine the specimens of older species with outdated morphological descriptions.

According to the ground pattern of Tegastidae proposed by Seifried (2003), the palmar margin of the maxillipedal basis of tegastid species has one proximal short seta or spine and one distal pad-like sensory element, which has been variously described as a mushroom-like stalked structure by Wells (2007) a scaphoid by Lang (1965), a tongue-like process by Bartsch (1994, 1995, 1999) and a spinulose pad by Huys et al. (1996). Wells (2007) suggested that the latter element, along with rows of spinules or setules on the proximal part, enhances the grasping ability of the maxilliped in tegastid species. The proximal short seta of the maxillipedal basis has been observed in most tegastid species. However, Syngastes species exhibit a peculiar form of tubercle or a cylindrical (button-like) process, instead of the proximal seta in the position where the proximal seta should be; an exception is Syngastes serratus Lang, 1965, which - like Smacigastes methanophilus - has no proximal elements on the maxillipedal basis. We presume that these elements are homologous structures, based on their position. It is likely that this morphological change increases the grasping ability, aiding Syngastes species in the attachment to algal substrata. Most Syngastes species are typically associated with macroalgae and seagrass in shallow waters, subject to more challenging environmental changes (such as rough waves) than the deep-sea-dwelling Smacigastes species. In contrast, the loss of the distal pad-like process, as well as a reduction of cephalosomal appendages (as mentioned above), are sometimes observed in species that have symbiotic associations with other invertebrates, including Aglaogastes cnidicus (Humes, 1981) (hydroid), T. acroporanus (scleractinian coral), T. gemmeus (scleractinian coral) and T. paulipes (scleractinian coral; Humes 1981a, 1984; Huys 2016).

T. Scott (1894) described a tegastid species as Amymone andrewi (= Tegastes andrewi) from São Thomé Island in the Gulf of Guinea, but his insufficient description and illustrations are limited to the habitus and part of the cephalosomal appendages. Although complete information regarding the thoracic legs is unavailable, this species has been conventionally assigned to the genus Tegastes (Wells 2007). However, the structure of the maxilliped provides a hint regarding the taxonomic status of T. andrewi. The palmar margin of the endopod has a proximal tubercle, which could be considered a 
powerful autapomorphy of the genus Syngastes (see T. Scott 1894: plate 10, Fig. 1); this aspect indicates a close relationship between T. andrewi and Syngastes species. Therefore, we have removed this species from the genus Tegastes and tentatively transferred it to the genus Syngastes as Syngastes andrewi (T. Scott, 1894) comb. nov., pending a redescription.

Ivanenko and Defaye (2004) established the deep-sea genus Smacigastes for $S$. micheli and assumed this genus to be the most primitive group in the family Tegastidae, based on the following distinct plesiomorphic features: (1) the integument of body and appendages is weakly chitinised; (2) the antennules of females and males are 8- and 10-segmented, respectively; (3) both rami of P2-P4 are 3-segmented, whereas the three subsequently described species ( $S$. barti, $S$. methanophilus and $S$. pumila sp. nov.) have 2-segmented exopods in P2-P3; (4) the urosome is composed of five urosomites, including a genital double-somite in both sexes; (5) the caudal rami of both sexes are elongate, approximately 3 -fold longer than their width; and (6) the female P6 with two elements is present and observable. Comparison of the morphology of cephalosomal appendages of Smacigastes with that of other tegastid genera also supports their assumption, whereby Smacigastes retains the following plesiomorphic states of tegastid species: (1) the antennary basis of both $S$. barti and $S$. micheli has an abexopodal seta, which has not been reported in other tegastid species; (2) the distal endopodal segment of the antenna in all Smacigastes species has a lateral armature composed of four setae, whereas three setae are present in Feregastes wellensi Fiers, 1986, two setae are present in most tegastid species and no setae are present in Arawella alexandri Cottarelli \& Baldari, 1987; (3) the endopod of the mandible has a lateral seta in all Smacigastes species, as well as in Arawella alexandri, Parategastes sphaericus (Claus, 1863), Syngastes foveatus Bartsch, 1994, Syngastes pseudofoveatus Kim, Jung \& Yoon, 2016, T. falcatus (Norman, 1869), T. fernandici Pallares, 1979, T. knoepffleri Médioni \& Soyer, 1967, T. okinawaensis and T. pygmaeus, but it is absent in the other tegastid species; and (4) the exopodal lobe of the mandible of Smacigastes micheli has three setae, while other tegastid species have 0-2 setae (Sars 1904; Médioni and Soyer 1967; Marcus 1977; Pallares 1979; Fiers 1986; Cottarelli and Baldari 1987; Bartsch 1994; Ivanenko et al. 2008; Back et al. 2010; Kim et al. 2016). Ivanenko et al. (2008) described the copepodid development of $T$. falcatus. The maxillule of the copepod phase I has a 1-segmented exopod with three setae, but this segment is reduced into a seta in the adult. Considering this feature, the 1-segmented exopod of the maxillule in Smacigastes is more primitive than the single seta present in Aglaogastes cnidicus, F. wellensi, P. conexus Humes, 1984, P. sphaericus, T. falcatus, T. gemmeus, T. paulipes and T. singularisaetus; moreover, the exopod is absent in Arawella alexandri, P. herteli Jakobi, 1953 and T. acroporanus (Sars 1904; Jakobi 1953; Marcus 1977; Humes 1981a, b, 1984; Fiers 1986; Cottarelli and Baldari 1987; Ivanenko et al. 2008).
Amongst Smacigastes species, $S$. micheli is the most primitive, based on the presence of three setae on the mandibular exopodal lobe; additionally, both rami of P2-P4 have three segments. Conversely, S. barti exhibits more derived conditions within the genus, in terms of the following features: (1) the female antennules are 7-segmented (vs. 8-segmented); (2) the exopodal lobe of the mandibular palp is absent (vs. represented by 1-3 setae); (3) the endopod of the maxillule is represented by a single seta (vs. 2-3 setae); (4) the basis of the P1 has no inner seta (vs. setae are present in S. micheli and S. pumila sp. nov.); and (5) the exopod of the P1 has four setae (vs. five setae; Table 1).

Former records of Smacigastes were from the Atlantic and Pacific Oceans. Our discovery of $S$. pumila sp. nov. from the Central Indian Ridge extends the distribution area of Smacigastes. All representatives of Smacigastes have been found from deep-sea chemosynthetic habitats, such as hydrothermal vents ( $S$. barti, S. micheli and $S$. pumila sp. nov.), cold seeps (S. methanophilus) and wood falls (undescribed Smacigastes species) (Gollner et al. 2008; Plum and Martínez Arbizu 2009). Hydrothermal vent fluids with high temperature cause the temporal gradients of the surrounding seawater (maximum temperature are usually less than $50{ }^{\circ} \mathrm{C}$ ) in the vent fauna (Govenar 2010). Gollner et al. (2008) suggested that $S$. barti has reduced tolerance to high temperatures and Ivanenko et al. (2012) found out that the abundance of $S$. micheli was relatively higher in the low temperatures $\left(4.8-7.5^{\circ} \mathrm{C}\right)$. The OVF, the type locality of $S$. pumila sp. nov., is also known to be an ultramafic-hosted hydrothermal system with the low temperatures (Kim et al. 2020). Therefore, Smacigastes species seem to prefer relatively low temperatures. The occurrence of S. pumila sp. nov. from the OVF dominated by bathymodiolin mussels reflects their preference of hard-substrate nutrient-rich environment as suggested by Gollner et al. (2008). It seems that mussel shells provide a harbour for filamentous bacteria that are probably food sources of Smacigastes species as suggested by Ivanenko et al. (2012).

\section{Acknowledgements}

The authors thank the captain and crews of the RV ISABU for their support and assistance with the sample collection. We also express our gratitude to editor Dr Kay Van Damme and two reviewers, Dr Viatcheslav N. Ivanenko and Dr Kai Horst George, for their helpful advice and comments on the manuscript. This research work was conducted by the project 'Understanding the deep-sea biosphere on seafloor hydrothermal vents in the Indian Ridge' of the Korea Institute of Marine Science and Technology Promotion (KIMST) funded by Ministry of Oceans and Fisheries, Kores (No. 20170411) and by KIOST (PM61740). This work was also supported by a research programme of KIMST (No. 20170431) and by a grant (2018R1A6A3A01012703) of the National Research Foundation of South Korea (NRF) to JG Kim. 


\section{References}

Back J, Huys R, Lee W (2010) A new species of the genus Tegastes (Copepoda: Harpacticoida: Tegastidae) from hydrothermal vents in the Okinawa Trough. Zoological Science 27(8): 678-688. https://doi.org/10.2108/zsj.27.678

Bartsch I (1993) Syngastes craterifer, ein neuer Tegastide (Harpacticoida, Copepoda) von Sudwestaustralien. Mitteilungen aus dem Hamburgischen Zoologischen Museum und Institut, Hamburg 90: 187-195.

Bartsch I (1994) Three new species of Syngastes from south-western Australia (Tegastidae, Harpacticoida, Copepoda). Spixiana 17(2): 161-173.

Bartsch I (1995) A new tegastid (Tegastidae: Harpacticoida: Copepoda) from southwestern Australia: Syngastes dentipes sp. nov. Records of the Western Australian Museum 17: 221-226.

Bartsch I (1999) Three new species of Syngastes (Tegastidae, Harpacticoida, Copepoda) from Western Australia. In: Walker DI, Wells FE (Eds) Proceedings of the Ninth International Marine Biological Workshop. The seagrass flora and fauna of Rottnest Island, Western Australia. Held at Rottnest Island (Western Australia), January 1996. Western Australian Museum, Perth, 295-313.

Boxshall GA, Halsey SH (2004) An Introduction to Copepod Diversity. The Ray Society, London, 966 pp.

Brady GS (1910) Die marinen Copepoden der Deutschen Südpolar-Expedition 1901-1903. I. Über die Copepoden der Stämme Harpacticoida, Cyclopoida, Notodelphyoida und Caligoida. Deutsche Südpolar-Expedition 1901-1903 11(Zoologie 3): 499-593.

Chang CY (2013) A new species of Cletocamptus Copepoda (Harpacticoida, Canthocamptidae) from salt marshes in Korea. Animal Systematics, Evolution and Diversity 29(3): 227-237. https:// doi.org/10.5635/ASED.2013.29.3.227

Claus C (1860) Beiträge zur Kenntnis der Entomostraken. Erstes Heft. Marburg 1: 1-28. https://doi.org/10.1002/prac.18600790109

Claus C (1863) Die frei lebenden Copepoden mit besonderer Berücksichtigung der Fauna Deutschlands, der Nordsee und des Mittelmeeres. Verlag von Wilhelm Engelmann, Leipzig, 230 pp. https:// doi.org/10.5962/bhl.title.58676

Corgosinho PHC, Martínez Arbizu P, Reid JW (2008) Revision of the genus Murunducaris (Copepoda: Harpacticoida: Parastenocarididae), with descriptions of two new species from South America. Journal of Crustacean Biology 28(4): 700-720. https://doi. org/10.1651/07-2907.1

Cottarelli V, Baldari F (1987) Meiobenthic Tegastidae from Salomon Atoll (Chagos Islands): Arawella alexandri g. n. sp. n. Fragmenta Entomologica 20(2): 273-282.

Cuvelier D, Beesau J, Ivanenko VN, Zeppilli D, Sarradin PM, Sarrazin J (2014) First insights into macro- and meiofaunal colonisation patterns on paired wood/slate substrata at Atlantic deep-sea hydrothermal vents. Deep-Sea Research Part I: Oceanographic Research Papers 87: 70-81. https://doi.org/10.1016/j.dsr.2014.02.008

Desbruyères D, Segonzac M, Bright M (2006) Handbook of Deep-Sea Hydrothermal Vent Fauna. Denisia 18. Biologiezentrum der Oberösterreichischen Landesmuseen, Linz, 544 pp.

Fiers F (1986) Feregastes wellensi n. gen., n. sp., a new genus of the family Tegastidae (Copepoda, Harpacticoida) from the Andaman Islands. Crustaceana 51(3): 277-285. https://doi.org/10.1163/156854086X00430

Goffredi SK, Johnson S, Tunnicliffe V, Caress D, Clague D, Escobar E, Lundsten L, Paduan JB, Rouse G, Salcedo DL, Soto LA, Spelz-Madero R, Zierenberg R, Vrijenhoek R (2017) Hydrothermal vent fields discovered in the southern Gulf of California clarify role of habitat in augmenting regional diversity. Proceedings of the Royal Society B: Biological Sciences 284(1859): e20170817. https://doi.org/10.1098/rspb.2017.0817

Gollner S, Ivanenko VN, Martínez Arbizu P (2008) A new species of deep-sea Tegastidae (Crustacea: Copepoda: Harpacticoida) from $9^{\circ} 50$ 'N on the East Pacific Rise, with remarks on its ecology. Zootaxa 1866: 323-336. https://doi.org/10.11646/zootaxa.1866.1.16

Govenar B (2010) Shaping vent and seep communities: Habitat provision and modification by foundation species. In: Kiel S (Ed.) The Vent and Seep Biota. Topics in Geobiology, Vol 33. Springer, Dordrecht, 403-432. https://doi.org/10.1007/978-90-481-9572-5_13

Hashimoto J, Ohta S, Gamo T, Chiba H, Yamaguchi T, Tsuchida S, Okudaira T, Watabe H, Yamanaka T, Kitazawa M (2001) First hydrothermal vent communities from the Indian Ocean discovered. Zoological Science 18(5): 717-721. https://doi.org/10.2108/zsj.18.717 Heip C, Vincx M, Vranken G (1985) The ecology of marine nematodes. Oceanography and Marine Biology, An Annual Review 23: 399-489.

Heptner MV, Ivanenko VN (2002) Copepoda (Crustacea) of hydrothermal ecosystems of the World Ocean. Arthropoda Selecta 11(2): 117-134.

Humes AG (1981a)A new species of Tegastes (Copepoda: Harpacticoida) associated with a scleractinian coral at Enewetak Atoll. Proceedings of the Biological Society of Washington 94(1): 254-263.

Humes AG (1981b) Harpacticoid copepods associated with Cnidaria in the Indo-west Pacific. Journal of Crustacean Biology 1(2): 227-240. https://doi.org/10.2307/1548161

Humes AG (1984) Harpacticoid copepods associated with cnidarians in the tropical Pacific Ocean. Zoologica Scripta 13(3): 209-221. https://doi.org/10.1111/j.1463-6409.1984.tb00038.x

Humes AG, Segonzac M (1998) Copepoda from deep-sea hydrothermal sites and cold seeps: description of a new species of Aphotopontius from the East Pacific Rise and general distribution. Cahiers de Biologie Marine 39(1): 51-62.

Huys R (2016) Harpacticoid copepods - their symbiotic associations and biogenic substrata: a review. Zootaxa 4174(1): 448-729. https:// doi.org/10.11646/zootaxa.4174.1.28

Huys R, Boxshall GA (1991) Copepod Evolution. The Ray Society, London, $468 \mathrm{pp}$.

Huys R, Conroy-Dalton S (2000) Generic concepts in the Clytemnestridae (Copepoda, Harpacticoida), revision and revival. Bulletin of the Natural History Museum, London, Zoology 66(1): 1-48.

Huys R, Gee JM, Moore CG, Hamond R (1996) Marine and Brackish Water Harpacticoid Copepods. Part 1. Keys and notes for identification of the species, 51. Field Studies Council, Shrewsbury, 352 pp.

Ivanenko VN, Corgosinho PHC, Ferrari F, Sarradin P-M, Sarrazin J (2012) Microhabitat distribution of Smacigastes micheli (Copepoda: Harpacticoida: Tegastidae) from deep-sea hydrothermal vents at the Mid-Atlantic Ridge, 37 degrees N (Lucky Strike), with a morphological description of its nauplius. Marine Ecology 33: 246-256. https://doi.org/10.1111/j.1439-0485.2011.00484.x

Ivanenko VN, Defaye D (2004) A new and primitive genus and species of deep-sea Tegastidae (Crustacea, Copepoda, Harpacticoida) from the Mid-Atlantic Ridge, $37^{\circ} \mathrm{N}$ (Azores triple junction, Lucky Strike). Cahiers de Biologie Marine 45(3): 255-268.

Ivanenko VN, Defaye D (2006) Copepoda. In: Desbruyères D, Segonzac M, Bright M (Eds) Handbook of Deep-Sea Hydrothermal Vent Fauna. Denisia, Linz, 316-355.

Ivanenko VN, Ferrari FD, Dahms HU (2008) Copepodid development of Tegastes falcatus (Norman, 1868) (Copepoda, Harpacticoida, Tegastidae) with a discussion of the male genital somite. Proceedings 
of the Biological Society of Washington 121(2): 191-225. https:// doi.org/10.2988/07-32.1

Ivanenko VN, Ferrari FD, Defaye D, Sarradin PM, Sarrazin J (2011) Description, distribution and microhabitats of a new species of Tisbe (Copepoda: Harpacticoida: Tisbidae) from a deep-sea hydrothermal vent field at the Mid-Atlantic Ridge ( $37^{\circ} \mathrm{N}$, Lucky Strike). Cahiers de Biologie Marine 52: 89-106. https://doi.org/10.1111/j.1439-0485.2011.00484.x

Jakobi H (1953) Neue Tegastiden (Harpacticoida-Copepoda) von der Kueste Santa Catarinas. Dusenia 4(2): 173-180.

Jang S-J, Ho P-T, Jun SY, Kim D, Won Y-J (2020) A newly discovered Gigantidas bivalve mussel from the Onnuri Vent Field in the northern Central Indian Ridge. Deep-Sea Research I: Oceanographic Research Papers 161: e103299. https://doi.org/10.1016/j.dsr.2020.103299

Kim J, Son S-K, Kim D, Pak S-J, Yu OH, Walker SL, Oh J, Choi SK, Ra K, Ko Y, Kim K-H, Lee J-H, Son J (2020) Discovery of active hydrothermal vent fields along the Central Indian Ridge, $8-12^{\circ} \mathrm{S}$. Geochemistry, Geophysics, Geosystems 21(8): e2020GC009058. https://doi.org/10.1029/2020GC009058

Kim JG, Jung TW, Yoon SM (2016) Two new species of the genus Syngastes (Copepoda, Harpacticoida, Tegastidae) from South Korea. Crustaceana 89(4): 431-458. https://doi.org/10.1163/15685403-00003533

Lang K (1965) Copepoda Harpacticoidea from the Californian Pacific coast. Kunglieren svenska Vetenskapsakademiens Handlingar 10(2): 1-560.

Lee J, Kim D, Kim I-H (2020) Copepoda (Siphonostomatoida: Dirivultidae) from hydrothermal vent fields on the Central Indian Ridge, Indian Ocean. Zootaxa 4759(3): 301-337. https://doi.org/10.11646/ zootaxa.4759.3.1

Marcus A (1977) The family Tegastidae Sars (Copepoda, Harpacticoida) from the Indian Ocean. Travaux du Museum d'Histoire Naturelle 'Grigore Antipa' 18: 73-87.

Marcus A, Masry D (1970) Tegastes georgei n. sp. a new harpacticoid (Crustacea, Copepoda) found on corals in the Gulf of Elat. Israel Journal of Zoology 19(3): 169-174.

Médioni A, Soyer J (1967) Copépodes Harpacticoïdes de Banyuls-surMer. 6. Nouvelles formes associées a des Bryozoaires. Vie et Milieu A 18(2): 317-343.

Monard A (1935) Les Harpacticoides marins de la region de Salammbo. Bulletin de la Station Oceanographie Salammbo 34: 1-94.

Nakamura K, Takai K (2015) Geochemical constraints on potential biomass sustained by subseafloor water-rock interactions. In: Ishibashi J-i, Okino K, Sunamura M (Eds) Subseafloor Biosphere Linked to Hydrothermal Systems. Springer, Tokyo, 11-30. https://doi. org/10.1007/978-4-431-54865-2_2

Pallares RE (1979) Copépodos harpactcoídeos marinos de Tierra del Fuego (Argentina). Isla de Los Estados III. Contribución Científica del Centro de Investigación de Biología Marina, Buenos Aires 142: 1-22.

Plum C, Martínez Arbizu P (2009) Discovery of Smacigastes Ivanenko \& Defaye, 2004 (Copepoda: Harpacticoida: Tegastidae) in a deepsea cold seep, with the description of a new species from the Gulf of Mexico. Zootaxa 2096: 338-355. https://doi.org/10.11646/zootaxa.2096.1.20

Plum C, Pradillon F, Fujiwara Y, Sarrazin J (2017) Copepod colonization of organic and inorganic substrata at a deep-sea hydrothermal vent site on the Mid-Atlantic Ridge. Deep-Sea Research Part II: Topical Studies in Oceanography 137: 335-348. https://doi. org/10.1016/j.dsr2.2016.06.008

Rogers AD, Tyler PA, Connelly DP, Copley JT, James R, Larter RD, Linse K, Mills RA, Garabato AN, Pancost RD, Pearce DA, Polunin
NV, German CR, Shank T, Boersch-Supan PH, Alker BJ, Aquilina A, Bennett SA, Clarke A, Dinley RJ, Graham AG, Green DR, Hawkes JA, Hepburn L, Hilario A, Huvenne VA, Marsh L, Ramirez-Llodra E, Reid WD, Roterman CN, Sweeting CJ, Thatje S, Zwirglmaier K (2012) The discovery of new deep-sea hydrothermal vent communities in the southern ocean and implications for biogeography. Plos Biology 10(1): e1001234. https://doi.org/10.1371/journal.pbio.1001234

Sars GO (1904) Copepoda Harpacticoida. Parts V \& VI. Harpacticidae (concluded), Peltidiidae, Tegastidae, Porcellidiidae, Idyidae (part). An account of the Crustacea of Norway, with short descriptions and figures of all the species 5: 57-80. [pls. 33-48]

Saetang T, Maiphae S (2015) A new species of Parategastes Sars, 1904 from the Thale Noi Lake, southern Thailand (Copepoda, Harpacticoida, Tegastidae). Zoosystematics and Evolution 91(2): 167-176. https://doi.org/10.3897/zse.91.5283

Sarrazin J, Legendre P, de Busserolles F, Fabri M-C, Guilini K, Ivanenko VN, Morineaux M, Vanreusel A, Sarradin P-M (2015) Biodiversity patterns, environmental drivers and indicator species on a high-temperature hydrothermal edifice, mid-Atlantic ridge. Deep-Sea Research II: Topical Studies in Oceanography 121: 177192. https://doi.org/10.1016/j.dsr2.2015.04.013

Scott T (1894) Report on Entomostraca from the Gulf of Guinea, collected by John Rattray, B.Sc. Transactions of the Linnean Society of London, Series 2, Zoology 6(1): 1-161. https://doi. org/10.1111/j.1096-3642.1894.tb00660.x

Seifried S (2003) Phylogeny of Harpacticoida (Copepoda): Revision of "Maxillipedasphalea" and Exanechentera. Cuvillier Verlag, Göttingen, $266 \mathrm{pp}$.

Thompson IC, Scott A (1903) Report on the Copepoda collected by Professor Herdman, at Ceylon, in 1902. In: Herdman WA (Ed.) Report to the Government of Ceylon on the Pearl Oyster Fisheries of the Gulf of Manaar 1(Supplement 7): 227-307. https://doi.org/10.5962/ bhl.title. 59334

Wells JBJ (2007) An annotated checklist and keys to the species of Copepoda Harpacticoida (Crustacea). Zootaxa 1568: 1-872. https:// doi.org/10.11646/zootaxa.1568.1.1

Willems WR, Curini-Galletti M, Ferrero TJ, Fontaneto D, Heiner I, Huys R, Ivanenko VN, Kristensen RM, Kånneby T, MacNaughton MO, Martínez Arbizu P, Todaro MA, Sterrer W, Jondelius U (2009) Meiofauna of the Koster-area, results from a workshop at the Sven Lovén Centre for Marine Sciences (Tjärnö, Sweden). Meiofauna Marina 17: 1-34.

Willen E (2004) Harpacticoida (Crustacea, Copepoda) from a hydrothermal active submarine volcano in the New Ireland Fore-Arc system (Papua New Guinea) with the description of a new genus and species of Pseudotachidiidae. Meiofauna Marina 13: 113-135.

Willen E (2006) A new species of Copepoda Harpacticoida, Xylora calyptogenae spec. n., with a carnivorous life-style from a hydrothermally active submarine volcano in the New Ireland Fore-Arc system (Papua New Guinea) with notes on the systematics of the Donsiellinae Lang, 1948. Helgoland Marine Research 60(4): 257272. https://doi.org/10.1007/s10152-006-0040-9

Zeppilli D, Leduc D, Fontanier C, Fontaneto D, Fuchs S, Gooday AJ, Goineau A, Ingels J, Ivanenko VN, Kristensen RM, Neves RC, Sanchez N, Sandulli R, Sarrazin J, Sørensen MV, Tasiemski A, Vanreusel A, Autret M, Bourdonnay L, Claireaux M, Coquillé V, De Wever L, Rachel D, Marchant J, Toomey L, Fernandes D (2018) Characteristics of meiofauna in extreme marine ecosystems: a review. Marine Biodiversity 48(1): 35-71. https://doi.org/10.1007/ s12526-017-0815-Z 